\title{
Development of a fruit smoothie with solid albumen of green coconut
}

\author{
Nátali Silva Teixeira ${ }^{1^{*}}$ (D) Renata Torrezan ${ }^{2}$ Daniela De Grandi Castro Freitas-Sá ${ }^{2}$ \\ Sérgio Macedo Pontes $^{2}$ Leilson de Oliveira Ribeiro ${ }^{3}$ \\ Lourdes Maria Correa Cabral ${ }^{2}$ Virgínia Martins da Matta $^{2}$
}

${ }^{1}$ Departamento de Tecnologia de Alimentos, Universidade Federal Rural do Rio de Janeiro (UFRRJ), 23890-000, Seropédica, RJ, Brasil. E-mail: natalinutricao@gmail.com. ${ }^{*}$ Corresponding author.

${ }^{2}$ Embrapa Agroindústria de Alimentos, Rio de Janeiro, RJ, Brasil.

${ }^{3}$ Universidade Federal do Rio de Janeiro (UFRJ), Rio de Janeiro, RJ, Brasil.

\begin{abstract}
The present study aimed to develop a mixed smoothie drink using the solid albumen of the green coconut in its composition. Smoothie formulations were prepared following an experimental design, setting the solid albumen concentration at $20 \%$ and varying the contents of the acerola (Barbados Cherry), pineapple, and coconut water pulps, which corresponded to $80 \%$ of the total mass of the product. Response parameters evaluated were vitamin $C$ content, antioxidant capacity, and overall sensory acceptance. Ten formulations were evaluated. The ones that contained higher concentrations of acerola pulp had higher values of bioactive compounds but were not the most sensorially accepted. By means of the desirability function, a final formulation consisted of $52.8 \%$ of pineapple, $27.2 \%$ of acerola, and $20.0 \%$ of solid albumen of green coconut. This new formulation was well accepted, with a grade (score) 7 ("good"). It represents a good nutritional contribution and a source of vitamin $C$ which can contribute to add value to a co-product of the beverage industry.
\end{abstract}

Key words: product development, sensory analysis, tropical fruits, antioxidant capacity.

Desenvolvimento de um smoothie de frutas contendo albúmen sólido do coco verde

RESUMO: O objetivo deste trabalho foi desenvolver uma bebida mista do tipo smoothie utilizando o albúmen sólido do coco verde na sua composição. As formulações do smoothie foram elaboradas seguindo um planejamento experimental, fixando-se a concentração do albúmen sólido em $20 \%$ e variando-se os teores das polpas de acerola, abacaxi e água de coco, que totalizaram $80 \%$ da massa total do produto. Os parâmetros de resposta avaliados foram o teor de vitamina $C$, a capacidade antioxidante e a aceitação sensorial global. Foi observado que das dez formulações avaliadas, as que continham maiores concentrações de polpa de acerola, apresentaram valores superiores de compostos bioativos, porém não foram as mais aceitas sensorialmente. Por meio da função desejabilidade chegou-se a uma formulação final que consistiu de 52,8\% de abacaxi, 27,2\% de acerola e 20,0\% de albúmen sólido de coco verde. Esta nova formulação teve boa aceitação, com nota igual a 7 ("bom") e representa um bom aporte nutricional, sendo fonte de vitamina $C$, podendo contribuir para agregar valor a um coproduto da indústria de bebidas.

Palavras-chave: desenvolvimento de produto, análise sensorial, frutas tropicais, capacidade antioxidante.

\section{INTRODUCTION}

Brazil is the fourth largest producer of coconuts in the world, surpassed only by Indonesia, the Philippines, and India (FAOSTAT, 2014). In 2016, Brazilian coconut production reached a total of 1,896,124 tons (IBGE, 2016).

In the industries of bottled coconut water, the shells are generally discarded and, attached to it, the solid albumen (green coconut pulp). According to BENASSI et al. (2007), the solid albumen of the dwarf green coconut (coconut tree dwarf green variety) at 8.5 months corresponds to $3.32 \%$ of the fruit weight. Use of this pulp is an alternative to reduce the generation of residues in the coconut water industrialization process and avoid the waste of this co-product which can reach 80,000 tons per year.

SANTANA et al. (2011) characterized the green coconut pulp, which had $5.19 \%$ of carbohydrates, $92.70 \%$ humidity, $0.39 \%$ of lipids, $0.97 \%$ of protein, and $0.75 \%$ of ashes. Like coconut water, albumen also contains minerals and low fat and sugars, and can be used as an ingredient in the industry of fruit drinks. 
In this day and age, ready-to-drink smoothie beverages are sought after by consumers seeking both nutritional quality and practicality. These beverages are formulated from fruit, fruit juice, yogurt, milk or honey, have a semi-liquid consistency, and are packaged in bottles that are easy to handle. In addition, fruit smoothies contain dietary fiber, antioxidant substances, and nutrients that may contribute to reduce risk of developing chronic noncommunicable diseases (NOWICKA et al., 2016).

Different fruits can be used to obtain these products which contribute to the nutritional and sensorial characteristics of the beverage. The development of smoothies with different combinations of fruits has been reported (MARKOWSKI et al., 2017). In general, fruits that are used to make a smoothie contribute to the quality of these fruits based on their original characteristics e.g. acerola which stands out for its high content of vitamin $C$; the banana, which adds a sweet taste to this beverage; the pineapple which is a fruit that is widely consumed and appreciated, and which can contribute to the sweet-acid balance of the smoothie; the açaí palm which is rich in anthocyanins; among other fruits.

However, the thick consistency, similar to a "milk shake", is a determining characteristic for the acceptance or rejection of this type of beverages. Smoothies are prepared with typical ingredients. Yoghurt, frozen fruits, milk and ice are the ones most often used for making smoothies (SAFE FOOD, 2009). SANTANA et al. (2011) evaluated the functional properties of the green coconut pulp. Results of their study indicated that the ability of foam formation and emulsification, viscosity, and volume increased due to air aggregation similar to those obtained using milk, fat, and emulsifier in ice cream formulation. Considering this scenario, the present study aimed to develop a mixed smoothie drink (beverage) using the solid albumen of the green coconut in its composition.

\section{MATERIALS AND METHODS}

\section{Raw materials (basic ingredients)}

The solid albumen of the dwarf variety of green coconut and coconut water were provided by the coconut water franchise (chain store) "Rei do Coco" (Coconut King) located in Barra do Piraí, RJ, Brazil. The albumen was removed manually after water extraction, stored in flexible packages, and shipped under refrigeration to Embrapa Food Agri-industry Research Institute located in Rio de Janeiro, RJ, Brazil, where it was homogenized in a ultraprocessor (Nutri Ninja ${ }^{\mathrm{TM}}$ model BL492BR30, China).
For the initial study of the formulations, frozen pulps of acerola and pineapple (De Marchi, Jundiaí, SP, Brazil) were purchased from the Central of Supply of Rio de Janeiro State (CEASA, RJ, Brazil). For the validation of the selected formulation, we used freshly extracted pulp of fresh pineapple and acerola fruits that were purchased from the local stores in the municipality of Rio de JaneiroRJ, Brazil. Upon receipt, the fruits were washed and sanitized. Pineapple fruits were manually peeled and sliced for pulp extraction using a horizontal fruit pulp extraction machine manufactured by Itametal, model Bonina $0,25 \mathrm{df}$ (Itabuna, Brazil) with a $0.6 \mathrm{~mm}$ sieve. The acerola pulping extraction was carried out directly using a pulp machine since peeling and cutting were not required prior to the pulping of the fruit mass. All raw materials (basic ingredients) were kept (stored) in a freezing chamber at $-18^{\circ} \mathrm{C}$ until the experimental trials were carried out. The experiments and analysis were conducted in the pilot plants and laboratories of Embrapa Food Agri-Industry.

Formulation and characterization of raw material and smoothie

Based on preliminary tests, the concentration of the solid albumen of the green coconut was set at $20 \%(\mathrm{~m} / \mathrm{m})$ as it provided a desirable consistency for the beverage. Contents of the three other components (acerola pulp, pineapple pulp, and coconut water) were the independent variables of the blend planning (BRANCO \& GASPARETTO, $2005)$ which corresponded to $80 \%(\mathrm{~m} / \mathrm{m})$ of the product. Response parameters assessed were vitamin $\mathrm{C}$ content, antioxidant capacity, and overall sensory acceptability of the 10 formulations resulting from the planning (Table 1).

For the preparation of the formulations, the raw materials (ingredients) were weighed in the amounts established and were homogenized in an ultraprocessor (Nutri Ninja ${ }^{\mathrm{TM}}$, model BL492BR30, China). Formulations were pasteurized at $84^{\circ} \mathrm{C}$ for 40 s on a scraped surface heat exchanger (FT25D, Armfield, England), packed in an ultra-clean container chamber in pet bottles with previously sanitized screw caps, and immediately cooled.

All pasteurized formulations were evaluated for the presence of pathogenic microorganisms (Salmonella and coliforms at $45^{\circ} \mathrm{C}$ ) according to the American Public Health Association (APHA, 2001). Raw materials and different smoothie formulations were analyzed for physical-chemical parameters, vitamin C, and antioxidant capacity. Determination of total 
Table 1 - Experimental mixing design for smoothie made with the solid albumen of the green coconut $(20 \% \mathrm{~m} / \mathrm{m})$, with added acerola, pineapple, and coconut water.

\begin{tabular}{|c|c|c|c|c|c|c|}
\hline \multirow[t]{2}{*}{ Formulation } & \multicolumn{3}{|c|}{-----------Coded variables----------- } & \multicolumn{3}{|c|}{ 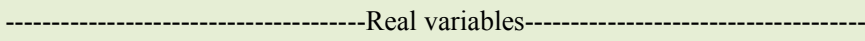 } \\
\hline & $\mathrm{X} 1$ & $\mathrm{X} 2$ & $\mathrm{X} 3$ & $(\%)$ Acerola & (\%) Pineapple & $(\%)$ Coconut water \\
\hline 1 & 1 & 0 & 0 & 80 & 0 & 0 \\
\hline 2 & 0 & 1 & 0 & 0 & 80 & 0 \\
\hline 3 & 0 & 0 & 1 & 0 & 0 & 80 \\
\hline 4 & $1 / 2$ & $1 / 2$ & 0 & 40 & 40 & 0 \\
\hline 5 & $1 / 2$ & 0 & $1 / 2$ & 40 & 0 & 40 \\
\hline 6 & 0 & $1 / 2$ & $1 / 2$ & 0 & 40 & 40 \\
\hline 7 & $1 / 3$ & $1 / 3$ & $1 / 3$ & 26.6 & 26.7 & 26.7 \\
\hline 8 & $2 / 3$ & $1 / 6$ & $1 / 6$ & 53.4 & 13.3 & 13.3 \\
\hline 9 & $1 / 6$ & $2 / 3$ & $1 / 6$ & 13.3 & 53.4 & 13.3 \\
\hline 10 & $1 / 6$ & $1 / 6$ & $2 / 3$ & 13.3 & 13.3 & 56.4 \\
\hline
\end{tabular}

phenolic compounds was carried out only for the raw materials and for the selected final formulation. Methods are presented below.

Soluble solids were determined by direct reading in a digital refractometer (ATAGO); the $\mathrm{pH}$ and titratable acidity were determined in an automatic titrator (Metrohm, 785 DMP Tritino); the total solids were determined by gravimetry (AOAC, 2005). Content of vitamin $\mathrm{C}$ was determined by a titration method (tritrimetry) using dichlorophenol-indophenol, and results were expressed as $\mathrm{mg}$ of ascorbic acid per $100 \mathrm{~g}$ of sample (SILVA, 1999). Antioxidant capacity was determined by the $\mathrm{ABTS}^{+}$radical capture assay (Sigma-Aldrich ${ }^{\circledR}$, Brazil) according to RE et al. (1999) and results were expressed in $\mu$ g equivalent of Trolox per gram of sample. For quantification of total phenolics, Folin Ciocalteu reagent (Sigma Aldrich ${ }^{\circledR}$, Germany) was used according to the protocol published by GEORGÉ et al. (2005). Results were expressed as $\mathrm{mg}$ of gallic acid per $100 \mathrm{~g}$ sample.

Sensory evaluation was performed in two different stages (steps) of the product development. In the first one, the global acceptability was one of the responses of the mixture planning; ten formulations were evaluated. This test was carried out in the Laboratory of Sensory Analysis of Embrapa Food Agri-Industry; 84 consumers of both sexes participated in this trial; consumer acceptance was measured by means of a hedonic scale of 9 points ranging from 1 - "strongly disliked it" - to 9 - "I liked it very much" - according to the method described by MEILGAARD et al. (1991). In the second stage, which aimed to verify the acceptance (acceptability) of the formulation selected by potential consumers, a new test was conducted at a store from the Hortifruti chain located in Recreio dos Bandeirantes neighborhood, city of Rio de Janeiro, RJ; 113 consumers of both sexes participated in this trial. In addition to the acceptability assessment based on the 9 point $\mathrm{P} \& \mathrm{~K}$ scale (ranging from 1 - "really bad (awful)" to 9 - really good (excellent)), consumers also answered questions about consumption habits of fruit juices and nectars and consumption intentions. In both tests, samples were presented in 50ml white plastic cups coded with 3 digit numbers and served at the refrigeration temperature.

\section{Data analysis}

Results were expressed as mean values \pm standard deviation of the determinations performed in triplicate and were statistically treated using analysis of variance (ANOVA) and Tukey test at 5\% significance with the software Statistica 7.0 (Statsoft Inc., Tulsa, OK, USA). Coefficients and interaction among variables were observed, generating the Pareto graph. The desirability function was used in order to determine the optimal proportions of each fruit. Therefore, we were able to simultaneously optimize the different response variables to obtain the best formulation possible. Values of the function are restricted to the interval (0-1) in which 0 represents an unacceptable value and 1 is the most desirable value (DERRINGER \& SUICH, 1980).

\section{RESULTS AND DISCUSSION}

\section{Physical-chemical characterization of raw materials (active ingredients)}

Table 2 presents the pulps, coconut water, and green coconut pulp. The values of $\mathrm{pH}$, titratable acidity, soluble solids, and total solids determined for 
both acerola pulp and pineapple pulp were within the limits established by Brazilian legislation (BRASIL, 2000). These parameters are important to assess pulp quality in relation to its conservation, maturity index, and standardization (CASTRO et al., 2015).

The green coconut pulp presented a higher content of soluble solids than that of coconut water. This finding is directly related to its sugar content which is compatible with the stage of maturation (maturity) close to the seventh month (CARVALHO et al., 2006). Both the water and the pulp have low acidity which was in the pulp. As a result, its $\mathrm{pH}$ is higher. In this $\mathrm{pH}$ range, coconut water and pulp may be susceptible to the proliferation of pathogenic bacteria (bacterial pathogens) (CERESER et al., 2008). Thus, the addition of acidic fruits in the formulations of smoothies also aims to contribute to the reduction of the $\mathrm{pH}$ which guarantees, along with the pasteurization, the microbiological safety of beverages. The fruit mixture provides sugars (pineapple and coconut pulp) and organic acids (pineapple and acerola) to the product. It also enables the development of a fruit drink without the addition of sugars and preservatives which contributes to the sensorial characteristics of the beverage. The coconut pulp also has a significant level of total solids which contribute to the consistency of the beverage.

The acerola and pineapple pulps also contain bioactive compounds such as phenolics and vitamin $\mathrm{C}$ which are substances that contribute to the antioxidant capacity of fruits, e.g. acerola which contains high levels of these compounds and; therefore, an antioxidant capacity $(51.22 \mu \mathrm{mol}$ Trolox. $\left.{ }^{-1}\right)$. These characteristics corroborated the use of these raw materials in the smoothie formulation.

\section{Characterization of the mixed green coconut smoothie \\ The Physical-chemical characteristics} of the 10 formulations are shown in table 3 . The acidity of the pasteurized smoothies ranged between 0.25 and $0.61 \mathrm{~g} .100 \mathrm{~g}^{-1}$ (expressed as citric acid). Formulations that presented higher values of acidity were F1, F2, F4, F8 and F9 which contained higher concentrations of acerola and pineapple. As a result, these formulations had the lower $\mathrm{pH}$ values. In a study conducted by MATSUURA \& ROLIN (2002), pineapple and acerola blends presented $\mathrm{pH}$ values between 3.42 and 3.81 and acidity between 0.71 and $0.87 \mathrm{~g}$ of citric acid $100 \mathrm{~g}^{-1}$. Our findings are in agreement with their findings considering the fact that the addition of both green coconut pulp and green coconut water contribute to an increase of the $\mathrm{pH}$ and to a decrease of the acidity of the formulations. Soluble solid contents of the formulations varied between 6.3 and $12.0^{\circ}$ Brix. As previously mentioned, beverages with higher contents were those that contained higher concentration of pineapple pulp due to the composition of the fruit.

Table 4 presents results of the dependent variables (vitamin $\mathrm{C}$, antioxidant capacity, and sensory acceptability) of the mixture planning for the 10 formulations. As expected, it is possible to observe a link between the increase in vitamin $\mathrm{C}$

Table 2 - Physicochemical characterization and bioactive compounds of the pulp of acerola, pineapple, green coconut, and coconut water.

\begin{tabular}{|c|c|c|c|c|}
\hline *Parameter & Acerola pulp & Pineapple pulp & Coconut water & Green coconut Pulp \\
\hline $\mathrm{pH}$ & $3.46 \pm 0.01$ & $3.54 \pm 0.01$ & $5.16 \pm 0.01$ & $6.53 \pm 0.00$ \\
\hline Soluble solids ( ${ }^{\circ}$ Brix) & $5.80 \pm 0.06$ & $12.00 \pm 0.06$ & $5.90 \pm 0.00$ & $7.50 \pm 0.12$ \\
\hline Acidity (g cítric acid $100 \mathrm{~g}^{-1}$ ) & $1.92 \pm 0.00$ & $0.66 \pm 0.00$ & $0.08 \pm 0.00$ & $0.06 \pm 0.00$ \\
\hline Vitamin C (mg. $\left.10 \mathrm{~g}^{-1}\right)$ & $773.76 \pm 25.48$ & $20.56 \pm 0.20$ & ND & ND \\
\hline Total solids $\left(\mathrm{g} .100 \mathrm{~g}^{-1}\right)$ & $6.59 \pm 0.18$ & $13.12 \pm 0.01$ & $7.53 \pm 0.04$ & $10.06 \pm 0.07$ \\
\hline Total phenolics (mg gallic acid. $100 \mathrm{~g}^{-1}$ ) & $467.81 \pm 5.04$ & $38.18 \pm 0.22$ & ND & $18.82 \pm 0.82$ \\
\hline Antioxidant capacity $\left(\mu \mathrm{mol}\right.$ Trolox. $\left.\mathrm{g}^{-1}\right)$ & $51.22 \pm 0.74$ & $1.06 \pm 0.07$ & ND & $0.75 \pm 0.05$ \\
\hline
\end{tabular}

*Average of 3 replicates \pm standard deviation. ND - not detected. 
Table 3 - Physicochemical characteristics of 10 formulations of pasteurized smoothie.

\begin{tabular}{lccc}
\hline Sample/Parameter & $\mathrm{pH}$ & Soluble solids $\left({ }^{\circ}\right.$ Brix $)$ & Acidity $\left(\mathrm{g}\right.$ cítric acid $\left.100 \mathrm{~g}^{-1}\right)$ \\
\hline F1 & $3.78 \pm 0.02$ & $6.3 \pm 0.15$ & $0.60 \pm 0.01$ \\
F2 & $3.83 \pm 0.00$ & $12.0 \pm 0.21$ & $0.61 \pm 0.00$ \\
F3 & $5.61 \pm 0.00$ & $6.0 \pm 0.00$ & $0.06 \pm 0.00$ \\
F4 & $3.86 \pm 0.01$ & $9.3 \pm 0.20$ & $0.60 \pm 0.01$ \\
F5 & $3.93 \pm 0.02$ & $6.4 \pm 0.12$ & $0.34 \pm 0.00$ \\
F6 & $4.01 \pm 0.01$ & $8.6 \pm 0.06$ & $0.35 \pm 0.01$ \\
F7 & $3.86 \pm 0.00$ & $8.0 \pm 0.10$ & $0.44 \pm 0.01$ \\
F8 & $3.76 \pm 0.00$ & $7.3 \pm 0.06$ & $0.51 \pm 0.00$ \\
F9 & $3.73 \pm 0.01$ & $10.2 \pm 0.06$ & $0.51 \pm 0.01$ \\
F10 & $4.19 \pm 0.01$ & $7.2 \pm 0.06$ & $0.25 \pm 0.00$ \\
\hline
\end{tabular}

${ }^{*}$ Data referring to the average of three replicates \pm standard deviation.

and antioxidant capacity values and acerola pulp proportions. This fruit is the source of this vitamin and is a natural ingredient which enriches the beverage. It should be emphasized that even after heat treatment of smoothies high levels of vitamin $\mathrm{C}$ were still present. Correlation coefficient $\left(\mathrm{R}^{2}\right)$ between vitamin $\mathrm{C}$ levels and the antioxidant capacity of the formulations was $0.9963(P<0.05)$. This finding confirmed the strong positive correlation between the two parameters and the contribution of this nutrient to the antioxidant capacity properties of formulated beverages.

In the 10 formulations of the pasteurized smoothie, coliform counts were lower than 10 CFU/100g considering the limit of the legislation (BRASIL, 2001). Salmonella, which standard is its absence in $25 \mathrm{~g}$, was not detected in any sample tested. Based on the analysis of variance, we noticed that the formulations F2, F6, and F9 had the highest mean of acceptance (scores close to 6.0 - liked a little bit (to a certain degree)) and did not present a significant difference $(P<0.05)$ between them. These formulations contained higher proportions of pineapple pulp which suggest that the soluble solid contents of this pulp contributed to the acceptability of the formulations as sweetness tends to influence consumer approval. A similar result was observed by NOWICKA et al. (2016). These researchers noted a relationship between the degree of sweetness and the acceptance of smoothies; those beverages with the highest proportions of apple and quince juice were the most accepted ones with a mean of scores of 8.2 and 7.5 , respectively.
The other smoothies, with high acidity had lower acceptability scores.

FARAONI et al. (2012) developed a mixed juice of mango, guava and acerola which achieve scores varying from 6.6 to 7.6. These marks were higher than those observed in the present study especially in formulations with a higher proportion of acerola and; therefore, higher acidity, that had lower sensory acceptability.

Based on the Pareto diagram (Figure 1), we were able to observe that these three components (ingredients) had a significant effect on the overall acceptance of the smoothie. The proportion of pineapple was the most influential variable followed by coconut water and ultimately acerola. This data shows statistically that the formulations with a higher content of pineapple pulp presented the greater acceptance among tasters.

The formulation selected based on desirability considering the balance between consumer responses contained $34 \%$ of acerola and $66 \%$ of pineapple without the addition of coconut water. Thus, the final formulation selected consisted of $52.8 \%$ of pineapple, $27.2 \%$ of acerola and $20 \%$ of solid albumen of green coconut, and presented $432.72 \mathrm{mg} .100 \mathrm{~g}^{-1}$ of vitamin C, $519.46 \mathrm{mg}$ of acid gallic acid. $100 \mathrm{~g}^{-1}$ of total phenolic compounds, and antioxidant capacity of $27.37 \mu \mathrm{mol}$ Trolox. $\mathrm{g}^{-1}$.

\section{Acceptance of the selected formulation}

Consumers profile who participated in the validation test of the final formulation that was selected 
Table 4 - Vitamin C content, antioxidant capacity and overall acceptance notes of the ten formulations of pasteurized smoothie.

\begin{tabular}{|c|c|c|c|}
\hline Sample & Vitamin C (mg $\left.100 \mathrm{~g}^{-1}\right)$ & Antioxidant capacity ABTS $\left(\mu \mathrm{mol}\right.$ Trolox $\left.\mathrm{g}^{-1}\right)$ & Global acceptability score \\
\hline F1 & $572.37 \pm 3.27$ & $52.35 \pm 1.82$ & $3.10^{\mathrm{e}}$ \\
\hline $\mathrm{F} 2$ & $20.29 \pm 0.12$ & $1.41 \pm 0.04$ & $6.13^{\mathrm{a}}$ \\
\hline F3 & $15.30 \pm 0.07$ & $0.67 \pm 0.03$ & $4.69^{\mathrm{bc}}$ \\
\hline $\mathrm{F} 4$ & $290.20 \pm 2.42$ & $27.74 \pm 0.49$ & $4.46^{\mathrm{bc}}$ \\
\hline F5 & $316.27 \pm 9.14$ & $29.08 \pm 0.77$ & $3.50^{\mathrm{de}}$ \\
\hline F6 & $19.93 \pm 0.17$ & $1.18 \pm 0.04$ & $5.96^{\mathrm{a}}$ \\
\hline F7 & $252.31 \pm 10.0$ & $19.12 \pm 0.28$ & $4.86^{\mathrm{b}}$ \\
\hline F8 & $395.56 \pm 9.15$ & $34.91 \pm 0.51$ & $4.05^{\mathrm{cd}}$ \\
\hline F9 & $132.83 \pm 12.94$ & $11.34 \pm 0.49$ & $5.80^{\mathrm{a}}$ \\
\hline F10 & $130.12 \pm 4.47$ & $9.02 \pm 0.57$ & $4.26^{\mathrm{bc}}$ \\
\hline
\end{tabular}

Mean of three replicates \pm standard deviation. ${ }^{*}$ Means with equal letters in the column do not differ by Tukey's test $(P<0.05)$.

showed that $42 \%$ consumed fruit drinks (nectar or juice) "once in a while (occasionally)" and 30\% "always" consumed this type of beverage. Based on these findings, we may infer that these individuals form a potential target audience for the beverage formulated in this study.

The average overall smoothie consumer acceptability score was 7 which correspond to "good". This finding indicated that the new formulation selected was well accepted by consumers. The majority of the consumers (98\%) considered smoothie a healthy drink; $92 \%$ of these individuals said that regular consumption of this type of beverage might help preventing illness since it contains vitamins, minerals, and bioactive

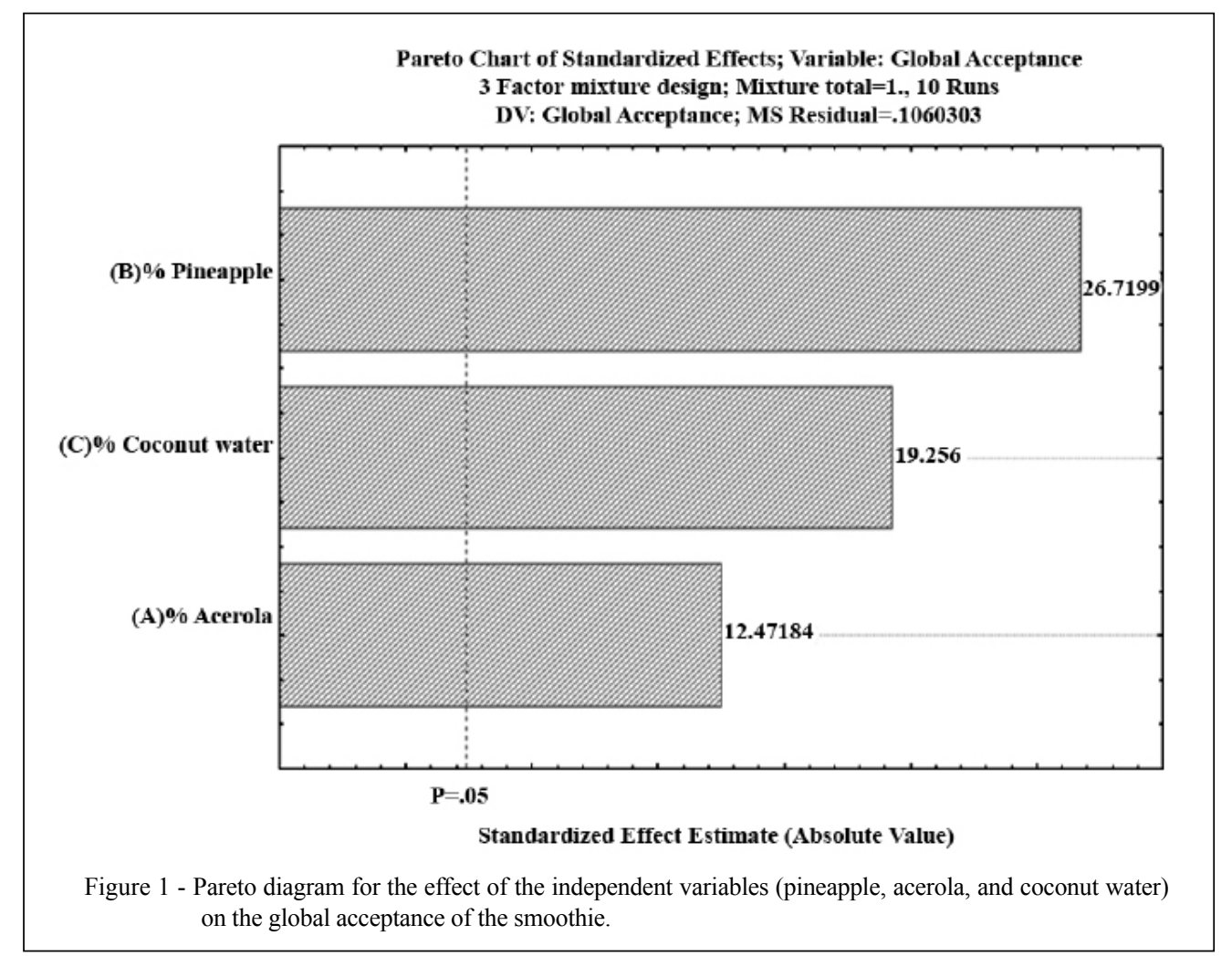

Ciência Rural, v.49, n.1, 2019. 
compounds. More than $50 \%$ of consumers would consume this beverage both for their liking and for their potential beneficial health benefits.

\section{CONCLUSION}

Results of the present study showed that it is possible to use solid albumen of green coconut in the development of a smoothie beverage. The selected formulation had good sensory acceptability. Considering the Physical-chemical composition of raw materials used in the preparation of these soft drinks, these ingredients may contribute to the nutritional supplementation (diet) of consumers. In addition, it provides a good source of vitamins, bioactive compounds, and antioxidant capacity. The industrialization of this beverage will also contribute to minimize the disposal of this co-product from the coconut water agroindustry by at least $20 \%$ by means of value aggregation.

\section{ACKNOWLEDGMENTS}

The authors gratefully acknowledge Coordenação de Aperfeiçoamento de Pessoal de Nível Superior (CAPES0 for the scholarships granted to graduate students and researchers, and to the franchise "Rei do Coco" for providing some of the ingredients used in the smoothie formulation and processing.

\section{BIOETICHS AND BIOSSECURITY COMMITTEE APPROVAL}

We the authors of the article titled "Development of a fruit smoothie with solid albumen of green coconut" do hereby declare for all due effects (intents) and purposes that the research project that generated the data presented in this publication was already submitted for evaluation by the Ethics Committee of the Plataforma Brasil (Brazil Platform), and that we are aware of the content of Resolution No. 466 issued on December 12, 2012 by the National Health Council <http://conselho.saude.gov.br/ resolucoes/2012/Reso466.pdf $>$ if humans in research studies. Therefore, the authors take full responsibility for the data presented in this study. The authors are available for any inquiries (questions) if there is any concern or need for further clarification if these requests come from competent bodies.

\section{DECLARATION OF CONFLICTING INTERESTS}

The authors declare no conflict of interest.

\section{AUTHORS' CONTRIBUTIONS}

All authors contributed equally for the conception and writing of the manuscript. All authors critically revised the manuscript and approved of the final version.

\section{REFERENCES}

AMERICAN PUBLIC HEALTH ASSOCIATION APHA. Compedium of methods for the microbiological examination of foods. 4. ed. Washington, DC. p. 676, 2001. AOAC. Association of Official Agricultural Chemists Official. Methods of Analysis of the Association of Analytical Chemists, 17th ed. Arlington: AOAC, 2005.

BENASSI, A. C. et al. Biometric characterization of coconut fruits, cocos nucifera L. green dwarf variety, at different stages of development. Revista Brasileira de Fruticultura, v. 29, n. 2, p. 302-307, 2007. Available from: <http://www.scielo.br/scielo. php? script $=$ sci_arttext\&pid $=$ S0100-29452007000200022>. Accessed: Sep. 10,2017. doi: 10.1590/S0100-29452007000200022.

BRANCO, I. G.; GASPARETTO, C. A. Rheological behavior of mixtures of mango pulp and orange and carrot juices using Casson model. Brazilian Journal of Food Techonology, v.8, n.2, p. 183189, 2005. Available from: <http://www.scielo.br/pdf/bjft/v15n3/ aop8610.pdf>. Accessed: Nov. 03, 2017. doi: 10.1590/S198167232012005000017.

BRASIL. Ministério da Agricultura, Abastecimento e Pecuária. Instrução Normativa $n^{\circ}$ 01, de 07 de Janeiro de 2000. Aprova o Regulamento Técnico geral para fixação dos Padrões de Identidade e Qualidade para polpa de fruta. Diário Oficial [da] União. Brasília, DF, 10 jan. 2000. Available from: <http://www. agricultura.gov.br/acesso-a-informacao/participacao-social/ consultas-publicas/documentos/01_09-secao-1-portaria-58.pdf $>$. Accessed: Nov. 05, 2017.

BRASIL. Ministério da Saúde. Agência Nacional de Vigilância Sanitária. Resolução RDC n ${ }^{\circ} 12$, de 02 de janeiro de 2001. Dispõe sobre os princípios gerais para o estabelecimento de critérios e padrões microbiológicos para alimentos. Diário Oficial [da] República Federativa do Brasil, Brasília, DF, 10 jan. 2001. Available from: $<$ http://portal.anvisa.gov.br/documents/33880/2568070/ RDC_12_2001.pdf/15ffddf6-3767-4527-bfac-740a0400829b >. Accessed: Nov. 05, 2017.

CARVALHO, J. M. DE. et al. Coconut water: Nutritional, functional and processing properties. Semina: Ciências Agrárias, v. 27, p. 437 452, 2006. Available from: $<$ http://www.uel.br/revistas/uel/index.php/ semagrarias/article/view/2472/2103>. Accessed: Sep. 10, 2017.

CASTRO, T. M. N. et al. Quality parameters of frozen fruit pulps. Revista Instituto Adolfo Lutz, v. 74, p. 426-36, 2015. Available from: $<$ https://www.researchgate.net/publication/306450595_Parametros de qualidade_de_polpas_de_frutas_congeladas $>$. Accessed: Oct. 15, 2017.

CERESER, N. D. et al. Foodbourne botulism. Ciência Rural, v. 38, p. $280-287,2008$. Available from: $<$ http://www.scielo.br/pdf/cr/ v38n1/a49v38n1.pdf>. Accessed: Oct. 27, 2017.

DERRINGER, G.; SUICH, R. Simultaneous optimization of several response variables. Journal of Quality Technology, v. 12, n. 4, p. 214-219, 1980. Available from: <https://www.tandfonline.com/doi/ abs/10.1080/00224065.1980.11980968> Accessed: Oct. 15, 2017. doi: $10.1080 / 00224065.1980 .11980968$.

FAOSTAT. Food and Agriculture Organization of The United Nations Statistics Division. 2014. Available from: $<$ http://faostat3. fao.org/browse/Q/*/E >. Accessed: Aug. 10, 2017. 
FARAONI, A. S. et al. Development of a mixed juice of mango, guava and acerola using a mix design. Ciência Rural, v. 42, n. 5, p. 911-917, 2012. Available from: <http:/www.scielo.br/pdf/cr/v42n5/ a12412cr5421.pdf>. Accessed: Oct. 08, 2017.

GEORGÉ, S. et al. Rapid determination of polyphenols and vitamin $\mathrm{C}$ in plant-derived products. Journal of Agricultural and Food Chemistry, v. 53, n. 5, p. 1370-1373, 2005. Available from: <https:// www.ncbi.nlm.nih.gov/pubmed/15740008>. Accessed: Oct. 08, 2017. doi: 10.1021/jf048396b.

IBGE - Instituto Brasileiro de Geografia e Estatística. Levantamento Sistemático da Produção Agrícola - Pesquisa Mensal de Previsão e Acompanhamento das Safras Agrícolas no Ano Civil, 2016. Available from: $<\mathrm{ftp}: / / \mathrm{ftp}$.ibge.gov.br/Producao Agricola/Levantamento_Sistematico_da_Producao_Agricola_ [mensal]/Fasciculo/2016/lspa_201612_20170222_133000.pdf $>$. Accessed: Aug. 10, 2017.

MARKOWSKI, J. et al. Impact of different thermal preservation technologies on the quality of apple-based smoothies. LWT - Food Science and Technology, v. 85 , p. 470-473, 2017. Available from: <https://www. sciencedirect.com/science/article/pii/S002364381730004X> Accessed: Oct. 27, 2017. doi: 10.1016/j.lwt.2017.01.004.

MATSUURA, F. C. A. U.; ROLIM, R. B. Evaluation of the addition of acerola juice in pineapple juice in order to produce a blend with a high content of vitamin C. Revista Brasileira de Fruticultura, v. 24, p. 138-141, 2002. Available from: <http://www.scielo. br/scielo.php?pid $=$ S0100-29452002000100030\&script $=$ sci abstract\&tlng=es>. Accessed: Nov. 14, 2017. doi: 10.1590/S010029452002000100030.
MEILGAARD, M. et al. Sensory evaluation techniques. Boca Raton: CRC Press, 1991. v.2, p. 354. NOWICKA, P. et al. Sensory attributes and changes of physicochemical properties during storage of smoothies prepared from selected fruit. LWT - Food Science and Technology. v. 71, p.102-109, 2016. Available from: $<$ https://www.sciencedirect.com/science/article/pii/S0023643816301578> Accessed: Oct. 26, 2017. doi: 10.1016/j.lwt.2016.03.021.

RE, R. et al. Antioxidant activity applying and improved ABTS radical cation decolorization assay. Free Radical Biological and Medicine, v. 26, n.9-10, p. 1231-1237, 1999. Available from: $<$ https:// www.sciencedirect.com/science/article/pii/S0891584998003153>. Accessed: Oct. 26, 2017. doi: 10.1016/S0891-5849(98)00315-3.

SANTANA, I. A. et al. Evaluation of green coconut (Cocos nucifera L.) pulp for use as milk, fat and emulsifier replacer in ice cream. Procedia Food Science, v. 1, p.1447-1453, 2011. Available from: <https:// www.sciencedirect.com/science/article/pii/S2211601X1100215X> Accessed: Oct. 30, 2017. doi: 10.1016/j.profoo.2011.09.214.

SAFE FOOD. Smoothies. Consumer knowledge, attitudes and beliefs around the nutritional content of smoothies, Safe food, February 2009. Available from: <http://www.safefood. eu/SafeFood/media/SafeFoodLibrary/Documents/Publications/ Research\%20Reports/9354-Smoothies-AW_web-FINAL-030309. pdf.> Accessed: Jun. 29, 2018.

SILVA, M. F. V. Efeito de diferentes tratamentos e embalagens no suco de acerola e caracterização dos teores de ácido ascórbico e das antocianinas durante o tempo de armazenamento. 1999. 224p. Tese (Doutorado em Tecnologia de Alimentos) - Faculdade de Engenharia de Alimentos, Universidade Estadual de Campinas (UNICAMP). 